\title{
Latent Tuberculosis Infection in a Migrant Agricultural Community in Baja California, Mexico
}

\author{
Richard S. Garfein · Jose Luis Burgos • Alfonso Rodriquez-Lainz • \\ Stephanie Brodine $\cdot$ Amanda Pietrucha $\cdot$ Amanda Rondinelli $\cdot$ \\ Rafael Laniado-Laborin · Elvira Ibarra $\cdot$ Alejandro Cañez $\cdot$ Miguel Fraga
}

Published online: 29 July 2010

(c) The Author(s) 2010. This article is published with open access at Springerlink.com

\begin{abstract}
The objectives were to estimate the prevalence and identify correlates of latent tuberculosis infection (LTBI) among residents of a migrant agricultural community in San Quintín, Baja-California, Mexico. Residents completed a questionnaire and had their blood tested for LTBI using the QuantiFERON ${ }^{\circledR}$-TB Gold In-Tube (QFT) assay. Among 133 participants, 39.8\% (95\% CI 31.5-48.7\%) tested QFT-positive. Having crossed the U.S.-Mexican border since living in San Quintin $(P=0.03)$, consuming unpasteurized milk $(P=0.02)$ and receiving health care at IMSS-Oportunidades in the last 6 months $(P=0.03)$ were independently associated with QFT-positivity. High LTBI prevalence in this community emphasizes the need for TB education and LTBI treatment for its residents. Association with travel to the U.S. suggests the potential for TB transmission across borders. Higher
\end{abstract}

R. S. Garfein $(\bowtie)$ J. L. Burgos · A. Rondinelli

School of Medicine, Division of Global Public Health,

University of California San Diego, 9500 Gilman Drive, mailstop 0507, La Jolla, San Diego, CA 92093-0507, USA e-mail: rgarfein@ucsd.edu

\section{A. Rodriquez-Lainz $\cdot$ S. Brodine $\cdot$ A. Pietrucha}

School of Public Health, San Diego State University, San Diego, CA, USA

A. Cañez $\cdot$ M. Fraga

Facultad de Medicina y Psicología, Universidad Autonoma de

Baja California, Tijuana, Baja California, México

R. Laniado-Laborin

Instituto de Servicios de Salud Publica, Tijuana, Baja California,

Mexico

E. Ibarra

Instituto de Servicios de Salud Publica, San Quintin, Baja

California, Mexico
QFT-positivity among those consuming unpasteurized milk could indicate M. bovis infection, previously reported among Mexican migrants living in U.S. border cities.

Keywords Tuberculosis - QuantiFERON-TB Gold · Mexico - Migrant - Latent tuberculosis infection · Border region

\section{Introduction}

Tuberculosis (TB) poses a major public health burden globally, disproportionately affecting underdeveloped countries and migrant populations $[1,2]$. The WHO estimated 9.27 million new cases and 1.7 million deaths occurred globally of TB in 2007 [3]. It is estimated that one-third of the world's population is infected with M. Tuberculosis. Most M. tuberculosis infections do not result in active TB and remain latent, depending on the virulence of the organism and the host response. The overall lifetime risk of latent tuberculosis infection (LTBI) progressing to active TB is estimated at $5-10 \%$ [3]. A person progressing from LTBI to active disease can infect between 10 and 15 people while untreated [4], complicating the challenges faced by underfunded TB control programs in regions with high TB burden [5].

The risk of progression from LTBI to active TB is increased by several factors including HIV coinfection, immunosuppression, malnutrition, chronic degenerative diseases, injection drug use, and residence or employment in congregate settings [6, 7]. Treatment of LTBI for 9 months with the drug isoniazid reduces the risk of progression to active TB by over $75 \%$ [8]. However, LTBI treatment in Mexico is hampered by universal immunization with the Bacillus Calmette-Guérin (BCG) that can 
cause a false positive reaction on the tuberculin skin test (TST) making this widely used TB test unreliable [9]. Newer tests, including the in vitro QuantiFERON ${ }^{\circledR}-$ TB Gold In-Tube assay (QFT) do not react to antigens in the BCG vaccine and thus give more sensitive and specific estimates of infection [7].

In North America, TB rates are higher in the border region of the United States (U.S.) and Mexico than their respective national rates. In both countries, the states forming each side of the border have TB rates 1.5 times the national average. Furthermore, $49 \%$ of the TB cases in the U.S. are foreign-born, of which $23 \%$ were born in Mexico [10] where Baja California has the highest TB rate (57.3 per 100,000 pop.) among the border states [11].

Residents of rural communities in Baja California often migrate from impoverished regions in the south of Mexico in hopes of migrating to the U.S. or to take advantage of higher paying jobs in the agricultural industry in Baja California. Once relocated to the northern border state of Baja California, residents may have opportunity for interaction with others in the U.S./Mexico border region through personal travel or visitation from others [12, 13]. Migrant populations with lower socioeconomic status, have higher rates of active TB and diagnosis can be delayed during migration; $[2,14]$ yet little is known about the prevalence of TB infection (LTBI) within these populations.

Through a collaboration between one Mexican and two U.S. universities, semi-annual clinics are conducted in an agricultural community (Colonia) that is open to all residents seeking primary medical care. The program, entitled VIIDAI [15], involves the efforts of medical and public health school faculty and students who organize and conduct clinical, epidemiological and health promotion activities during each trip. During one of these trips, a survey was conducted that included free TB testing. The aim of the study was to determine the prevalence and correlates of LTBI among adult residents of an agricultural community in San Quintín, Baja California, Mexico.

\section{Methods}

A cross-sectional study was conducted over a two-day period in October 2008 to determine the prevalence of LTBI among adults living in a migrant agricultural community (Colonia), in the Baja California's San Quintín Valley. Participants were recruited to complete a brief interview and provide a blood sample for QFT testing. All study procedures were approved by institutional review boards at University of California San Diego and Universidad Autonoma de Baja California. All participants gave written informed consent before undergoing any study procedures.
Study Setting

The Colonia is located in the San Quintín agricultural region of Baja California, roughly 200 miles south of the border with the U.S. Approximately 30,000-40,000 farm workers reside in the San Quintín Valley; 3,000-5,000 of whom reside in the Colonia we studied [16, 17]. Much of the population in the region, particularly among the Colonias, is comprised of migrants from outside of Baja California employed by the fruit and vegetable export industry [18].

\section{Sampling}

Study participants were recruited in two ways: (1) all eligible VIIDAI clinic patients were invited to participate after registering for a clinic appointment; and (2) households in the community were randomly selected and eligible residents in those households were invited to participate. Eligibility for the study included age at least 18 years old and residence in the Colonia. To avoid oversampling from potential clusters, only one adult per household could participate.

The clinic was established in a local primary school in the Colonia on a Saturday and Sunday when the school was not in session and most residents were not working. After the patients registered for the clinic, eligible individuals were invited to take part in the TB study. When more than one willing adult from the same household was present, a die was used to randomly select only one household member for the study.

A second sample was selected via door-to-door recruitment in the Colonia. Using maps created with Google Earth ${ }^{\circledR}$ in conjunction with notes from previous VIIDAI surveys, 16 randomly selected starting points were chosen and recruiters systematically approached every third household as they moved in a prearranged pattern through the community. At the households, residents were introduced to the study and invited to participate. Potential participants at both locations were asked if they had already participated and 'prohibited from retaking the survey. If a selected dwelling had no eligible participants present at the time of the visit, two additional attempts were made over the two-day study period to contact them.

\section{Survey Instrument}

Face-to-face interviews lasting approximately 30 min were conducted in semi-private settings by graduate students who were trained in research methods and ethics. Interviewers administered a standardized questionnaire that assessed sociodemographics, travel history, places of residence, years lived in each place, beliefs about tuberculosis 
transmission, active tuberculosis symptoms, past healthcare services received, and past TB diagnosis. Questionnaires were written in English, translated into Spanish and then translated back to English to ensure accuracy. The questionnaires were pilot-tested on persons with low socioeconomic status in Tijuana to verify their comprehensibility and cultural appropriateness.

Sociodemographic questions included age, sex, years of school completed, marital status, number of children, language(s) spoken, number of people per household, number of rooms per household, and occupation. Detailed residential (list of cities and states where participant lived for more than 6 months) and travel histories (frequency and reason for travel to the border region and the U.S.) were also obtained using maps as aids. For the purposes of the study, the border region was defined as the area $100 \mathrm{~km}$ south of the U.S./Mexico border (equivalent to 62 miles). Participants' knowledge of TB was assessed through a series of yes/no questions: Do you believe that (1) TB has a "sleeping" form, (2) infection risk increases with sharing personal items, (3) TB is spread through the air, and (4) TB can be cured by taking medicine. These questions were pilot tested for comprehension in this community and found to be readily understood. Previous history of TB diagnosis and treatment was gathered, along with history of contact with TB-infected persons. Since M. bovis infection can occur after consuming unpasteurized dairy products and produces positive QFT results [19], participants were asked, In the last 6 months, have you drank raw milk (leche bronca) or eaten unpasteurized cheese (queso fresco)? This is milk/cheese that has not been treated to kill germs [20].

After the interview, participants received pre-test counseling about the TB test and had blood drawn for the test. Following the questionnaire and blood draw, all participants received a small, non-monetary incentive and an information pamphlet about TB. They were also informed about how and when they would receive notification about their TB status and how to receive treatment if necessary.

\section{Tuberculosis Testing}

M. tuberculosis infection was detected by the QuantiFERON $^{\circledR}$-TB Gold In-Tube interferon gamma release assay (Cellestis, Ltd. Carnegie, Australia), an in vitro system that detects interferon gamma released by whole blood samples after introduction of ESAT-6, CFP-10, and TB7.7 proteins that mimic antigens specific to the M. tuberculosis complex present in both TB and LTBI [21]. In 2005, the U.S. Food and Drug Administration approved QFT for detection of $M$. tuberculosis infection, and the U.S. Centers for Disease Control and Prevention determined that QFT may be used to detect $M$. tuberculosis in all situations where TST is used [22].
Following the manufacturer's instructions, venous blood was drawn directly into three vacuum tubes provided with the test kit that contain heparin alone (nil control), heparin and TB antigens (test), or heparin and a mitogen (positive control). The tubes were shaken and placed in a portable incubator for 16-24 $\mathrm{h}$ before spinning them to separate the plasma for IFN- $\gamma$ quantification. The samples were transported at $4^{\circ} \mathrm{C}$ to Tijuana General Hospital for ELISA.

All results were sent to a collaborating clinician in San Quintín within 4 weeks so they could be provided to the participants. The clinician requested three sputum samples from QFT-positive participants to rule out active TB. Participants with active TB could receive free treatment through the Instituto de Servicios de Salud en el Estado de Baja California (ISESALUD). Those who were QFTpositive but sputum-negative (LTBI) were informed about the symptoms and risks for developing active disease.

Since the QFT assay detects $M$. tuberculosis infection, but does not differentiate between LTBI and active TB, we used self-reported TB symptoms to identify potential cases of active TB. The questionnaire included presence of clinical markers of active TB (e.g., cough lasting $>3$ weeks, fever or chills, night sweats, weight loss, hoarseness, enlarged lymph nodes, joint pain, fatigue, and hemoptysis). Participant reporting hemoptysis, or chronic cough plus $\geq 1$ other symptom, were considered suspicious for active TB and were immediately referred to the local public health center to rule out active TB. Similarly, when QFT results were ready approximately 6 weeks later, QFT-positive participants were urged to visit the local health center and provide sputum samples for testing to rule out active TB.

\section{Statistical Analysis}

Descriptive statistics were used to characterize participants by QFT status. Associations between participant characteristics and TB infection were evaluated first by Wilcoxon rank sum test or Fisher's exact test, followed by univariate and multivariable logistic regressions. All variables were considered for inclusion in multivariate analysis. A backward stepwise model selecting for main effects in the final model was performed. Once a model was determined, individual variables were selectively added and removed to provide a parsimonious model. At each step, likelihood ratio testing was used to compare nested models until only variables with $P$-values $<0.05$ remained in the final model [23].

\section{Results}

Of 119 eligible clinic patients, 110 (92\%) agreed to participate, 14 of which were excluded because they belonged to the same household as a participant (Fig. 1). Of 118 


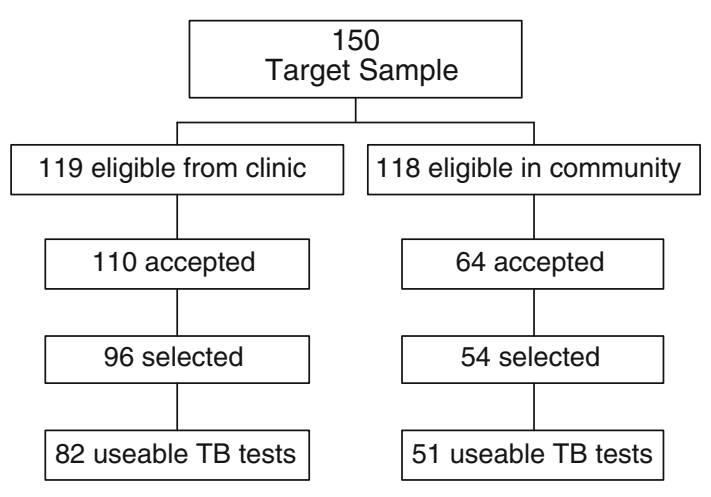

Fig. 1 VIIDAI study sample, San Quintín, Baja California, Mexico (2008). * Selection was made randomly among eligible adults when more than one household member was willing to participate in the study

eligible adults selected from the community households, 64 (54\%) agreed to participate, 10 were excluded because they belonged to the same household as a participant from the clinic. In total, 150 individuals were enrolled, of which 17 could not provide enough blood for the QFT test, leaving 133 individuals with complete interview and laboratory data for this analysis. Of the 133 participants, $37 \%$ were male and the median age was 35 years (range: 18-71). Only 7 participants $(5 \%)$ were born in San Quintín, the majority (75\%) of participants reported being born in the Mexican state of Oaxaca and $45 \%$ spoke an indigenous language (71\% Mixtec, $15 \%$ Triqui and $14 \%$ Zapotec). Half (50\%) were currently employed in the agricultural industry.

\section{Sample Characteristics by Recruitment Source}

As shown in Table 1, participants recruited at the clinic were more likely to speak an indigenous language (odds ratio $[\mathrm{OR}]=2.2, P=0.03$ ). No other differences were statistically significant.

\section{Univariate Analysis of QFT-Positivity}

Overall, 39.9\% (95\% CI 31.5-48.7\%) of participants tested positive on the QFT assay (Table 2). Age $\geq 30$ years $(P=0.06)$, living in the Colonia for more than 10 years $(P=0.06)$, and drinking unpasteurized milk (leche bronca) in the last 6 months $(P=0.06)$ all had a marginally significant association with testing QFT-positive. The prevalence of eating unpasteurized cheese (queso fresco) did not differ between QFT-positive and QFT-negative participants (64\% vs. $60 \%, P=0.72$ ).

Considering mobility and travel, Table 2 shows that participants who had traveled to the U.S. since living in the Colonia had a marginally significant association with QFTpositivity $(P=0.08)$, as did travel to the U.S. or border region or receiving visitors from the U.S. $(P=0.10)$.
TB symptoms, history, and knowledge were considered. Six participants from the clinic and four from the Colonia households reported symptoms suggestive of active TB (7.5\%); of which half $(n=5)$ were QFT positive. All 10 symptomatic participants subsequently received sputum testing for acid fast bacilli and clinical evaluation at the local health department, of which none had active TB. Almost one-third of participants had received care at IMSS Oportunidades, a Mexican government funded social program for underprivileged rural Mexicans, which was also marginally associated with QFT-positivity $(P=0.1)$. Only one participant responded correctly to all four TB questions and nine $(6.8 \%)$ did not have any correct answers. Correct responding to these questions was not associated with QFT-positivity.

\section{Multivariate Analysis of QFT-Positivity}

On multivariate logistic regression (Table 3), QFT-positivity was independently associated with reporting travel to the U.S. since living in the Colonia (adjusted OR $[\mathrm{AOR}]=2.72$, $P=0.03$ ), consuming unpasteurized milk in the last six months (AOR $=3.6, P=0.02)$, and receiving medical care at IMSS Oportunidades (AOR $=2.51, P=0.03$ ).

\section{Discussion}

This study found an LTBI prevalence of nearly $40 \%$ among migrant residents in a rural area in Baja California. Furthermore, over $90 \%$ of the residents were migrants from other Mexican states, primarily from Oaxaca, and more than one-third reported traveling to the U.S. or a border area since living in the Colonia, of which half crossed the U.S. Mexican border since living in the Colonia. This significant pool of latently infected individuals contributes to the high rate of active pulmonary TB cases in Mexico. With the recent availability of assays such as QFT to differentiate between BCG immune status and TB infection, strategies for treatment of LTBI may be cost-effective for improving the control of TB in Mexico, as has been achieved in neighboring U.S. [7].

The association between travel to the U.S. and presence of LTBI does not indicate whether exposure to M. Tuberculosis occurred prior to, during or after migration. However, since individuals with LTBI have a $10 \%$ lifetime risk for developing active TB, [3] which can be spread to others, the risk of TB spreading beyond the Colonia is a concern. Of participants crossing the border since living in San Quintín, most reported traveling to California (72\%) and cited economic reasons or permanent migration to the U.S. (85\%) as their reason for travel (data not shown). As a result Mexican and U.S. public health 
Table 1 Characteristics by recruitment site among 133 residents of an agricultural community in San Quintín, Mexico: October, 2008

\begin{tabular}{|c|c|c|c|c|}
\hline Characteristics & $\begin{array}{l}\text { Clinic } \\
(N=82) \\
n(\%)^{\mathrm{a}}\end{array}$ & $\begin{array}{l}\text { Community } \\
(N=51) \\
n(\%)^{\mathrm{a}}\end{array}$ & $\begin{array}{l}\text { Total } \\
(N=133) \\
n(\%)^{\mathrm{a}}\end{array}$ & $P$-value ${ }^{\mathrm{b}}$ \\
\hline \multicolumn{5}{|l|}{ Socio-demographic } \\
\hline Age, median $\left(\mathrm{IQR}^{\mathrm{c}}\right)$ & $36(29-49)$ & $32(27-41)$ & $35(28-42.5)$ & 0.16 \\
\hline Age $\geq 30$ years & $57(69.5 \%)$ & $30(58.8 \%)$ & $87(65.4 \%)$ & 0.26 \\
\hline Gender (female) & $53(64.6 \%)$ & $31(60.78 \%)$ & $84(63.2 \%)$ & 0.71 \\
\hline Years of school, median $\left(\mathrm{IQR}^{\mathrm{c}}\right)$ & $4.5(1-6)$ & $3(0-6)$ & $4(0-6)$ & 0.16 \\
\hline 6 years or more of school & $32(39 \%)$ & $17(33.3 \%)$ & $49(36.8 \%)$ & 0.58 \\
\hline Speaks indigenous language & $43(52.4 \%)$ & $17(33.3 \%)$ & $60(45.1 \%)$ & 0.03 \\
\hline Agricultural worker & $38(46.3 \%)$ & $29(56.9 \%)$ & $67(50.4 \%)$ & 0.29 \\
\hline Lived in the Colonia for more than 10 years & $49(59.8 \%)$ & $28(54.9 \%)$ & $77(57.9 \%)$ & 0.59 \\
\hline Born in the State of Oaxaca, Mexico & $65(79.3 \%)$ & $35(68.6 \%)$ & $100(75.2 \%)$ & 0.22 \\
\hline \multicolumn{5}{|l|}{ Mobility } \\
\hline Any travel since moving to San Quintín & $47(57.3 \%)$ & $31(60.8 \%)$ & $78(58.7 \%)$ & 0.72 \\
\hline Travel to US since living in San Quintín & $18(22.0 \%)$ & $7(13.7 \%)$ & $25(18.8 \%)$ & 0.26 \\
\hline Any travel to US or border or had visitors from US & $52(63.4 \%)$ & $27(51.0 \%)$ & $78(58.7 \%)$ & 0.21 \\
\hline \multicolumn{5}{|l|}{ TB Knowledge } \\
\hline Sleeping form of TB exists & $27(32.9 \%)$ & $17(33.3 \%)$ & $44(33.1 \%)$ & 1.00 \\
\hline TB can be treated with medications & $59(72.0 \%)$ & $31(60.8 \%)$ & $90(67.7 \%)$ & 0.19 \\
\hline Not transmitted by sharing utensils & $16(19.5 \%)$ & $7(13.7 \%)$ & $23(17.3 \%)$ & 0.48 \\
\hline Transmitted through air & $57(69.5 \%)$ & $33(64.7 \%)$ & $90(67.7 \%)$ & 0.57 \\
\hline All answers correct & $1(1.2 \%)$ & $0(0.0 \%)$ & $1(0.8 \%)$ & 1.00 \\
\hline All answers wrong & $4(4.9 \%)$ & $5(9.8 \%)$ & $9(6.8 \%)$ & 0.30 \\
\hline \multicolumn{5}{|l|}{ Health history } \\
\hline Symptoms suggestive of active TB & $6(7.3 \%)$ & $4(7.8 \%)$ & $10(7.5 \%)$ & 1.00 \\
\hline BCG scar & $58(70.7 \%)$ & $43(84.3 \%)$ & $101(75.9 \%)$ & 0.10 \\
\hline Drank unpasteurized milk in the past 6 months & $13(15.9 \%)$ & $3(5.9 \%)$ & $16(12.0 \%)$ & 0.11 \\
\hline Consumed unpasteurized cheese & $56(68.3 \%)$ & $26(51 \%)$ & $82(61.7 \%)$ & 0.07 \\
\hline Ever had contact with someone with TB disease & $30(36.6 \%)$ & $14(27.5 \%)$ & $44(33.1 \%)$ & 0.34 \\
\hline \multicolumn{5}{|l|}{ Access to health care } \\
\hline No use of healthcare in last 6 months & $19(23.2 \%)$ & $16(31.4 \%)$ & $35(26.3 \%)$ & 0.32 \\
\hline Used IMSS ${ }^{\mathrm{c}}$ in the last 6 months & $24(29.3 \%)$ & $16(31.4 \%)$ & $40(30.1 \%)$ & 0.85 \\
\hline Used IMSS ${ }^{\mathrm{c}}$ Oportunidades in the last 6 months & $18(22 \%)$ & $12(23.5 \%)$ & $30(22.6 \%)$ & 0.83 \\
\hline Used ISESALUD $^{c}$ in the last 6 months & $8(9.8 \%)$ & $4(7.8 \%)$ & $12(9.0 \%)$ & 0.77 \\
\hline \multicolumn{5}{|l|}{ QFT assay results } \\
\hline QFT positive & $37(45.1 \%)$ & $16(31.4 \%)$ & $53(39.9 \%)$ & 0.15 \\
\hline
\end{tabular}

a $n(\%)$ unless indicated otherwise

b $P$-values for comparing sample characteristics by recruitment site are from Wilcoxon rank sum test for continuous variables or Fisher's exact test for categorical variables

c Abbreviations: IQR interquartile range, IMSS Instituto Mexicano del Seguro Social, ISESALUD Instituto de Servicios de Salud Publica de Baja California

programs should have a vested interest in collaborating on the surveillance of TB infection and disease transmission among shared mobile populations, considering that the migration process can be a risk factor for TB transmission across international borders [2].

The association between consuming raw milk and QFTpositivity raises the concern of $M$. bovis infection, a zoonotic form of mycobacteria found in unpasteurized milk, as the source of LTBI among residents of San Quintín. Increased rates of $M$. bovis tuberculosis have been reported among Hispanic populations in U.S. border cities. The disease has lower survival compared to M. tuberculosis and is intrinsically resistant to pyrazinamide, a first line TB drug [24]. 
Table 2 Characteristics by QuantiFERON ${ }^{\circledR}-\mathrm{TB}$ Gold In-Tube (QFT) status among residents of an agricultural community in San Quintín, Mexico: October, 2008

\begin{tabular}{|c|c|c|c|c|c|}
\hline Characteristics & $\begin{array}{l}\text { QFT }+(N=53) \\
n(\%)^{\mathrm{a}}\end{array}$ & $\begin{array}{l}\text { QFT- }(N=80) \\
n(\%)^{\mathrm{a}}\end{array}$ & $\begin{array}{l}\text { Total }(N=133) \\
N(\%)^{\mathrm{a}}\end{array}$ & $\mathrm{OR}^{\mathrm{b}}(95 \% \mathrm{CI})$ & $P$-value \\
\hline \multicolumn{6}{|l|}{ Socio-demographic } \\
\hline Age, median $\left(\mathrm{IQR}^{\mathrm{b}}\right)$ & $36(29.5-45)$ & $33.5(28-41.5)$ & $35(28-42.5)$ & - & 0.25 \\
\hline Age $\geq 30$ years & $40(75.5 \%)$ & $47(58.8 \%)$ & $87(65.4 \%)$ & $2.16(0.9-4.7)$ & 0.06 \\
\hline Gender (female) & $35(66.0 \%)$ & $49(61.3 \%)$ & $84(63.2 \%)$ & $1.23(0.6-2.5)$ & 0.59 \\
\hline Years of school, median $\left(\mathrm{IQR}^{\mathrm{b}}\right)$ & $4(1-6)$ & $4(0-6)$ & $4(0-6)$ & - & 0.73 \\
\hline 6 years or more of school & $18(34.0 \%)$ & $31(38.8 \%)$ & $49(36.8 \%)$ & $0.8(0.4-1.7)$ & 0.59 \\
\hline Speaks indigenous language & $22(41.5 \%)$ & $38(47.5 \%)$ & $60(45.1 \%)$ & $0.8(0.4-1.6)$ & 0.59 \\
\hline Agricultural field worker & $29(54.7 \%)$ & $38(47.5 \%)$ & $67(50.4 \%)$ & $1.34(0.7-2.7)$ & 0.48 \\
\hline Lived in the Colonia for more than 10 years & $36(67.9 \%)$ & $41(51.3 \%)$ & $77(57.9 \%)$ & $2.01(0.9-4.2)$ & 0.06 \\
\hline Born in the State of Oaxaca, Mexico & $42(79.3 \%)$ & $58(72.5 \%)$ & $100(75.2 \%)$ & $1.45(0.6-3.3)$ & 0.42 \\
\hline Recruited at the Clinic & $37(69.8 \%)$ & $45(56.3 \%)$ & $82(61.7 \%)$ & $1.80(0.9-3.7)$ & 0.15 \\
\hline \multicolumn{6}{|l|}{ Mobility } \\
\hline Any travel since moving to San Quintin & $31(58.5 \%)$ & $47(58.8 \%)$ & $78(58.7 \%)$ & $0.99(0.49-2.0)$ & 1.00 \\
\hline Ever travel to US since living in San Quintin & $14(26.4 \%)$ & $11(13.8 \%)$ & $25(18.8 \%)$ & $2.25(0.9-5.4)$ & 0.08 \\
\hline Any travel to US or border or had visitors from US & $36(67.9 \%)$ & $42(52.5 \%)$ & $78(58.7 \%)$ & $1.92(0.9-3.9)$ & 0.10 \\
\hline \multicolumn{6}{|l|}{ TB knowledge (correct answer) } \\
\hline Sleeping form of TB exists & $16(30.2 \%)$ & $28(35.0 \%)$ & $44(33.1 \%)$ & $0.8(0.4-1.7)$ & 0.58 \\
\hline $\mathrm{TB}$ can be treated with medications & $38(71.7 \%)$ & $52(65.0 \%)$ & $90(67.7 \%)$ & $1.36(0.6-2.9)$ & 0.45 \\
\hline Not transmitted by sharing utensils & $6(11.3 \%)$ & $17(21.3 \%)$ & $23(17.3 \%)$ & $0.47(0.2-1.3)$ & 0.16 \\
\hline Transmitted through air & $40(75.5 \%)$ & $50(62.5 \%)$ & $90(67.7 \%)$ & $1.85(0.9-4.0)$ & 0.13 \\
\hline All correct & $1(1.9 \%)$ & $0(0.0 \%)$ & $1(0.8 \%)$ & - & 0.40 \\
\hline All wrong & $2(3.8 \%)$ & $7(8.8 \%)$ & $9(6.8 \%)$ & $0.41(0.1-2.0)$ & 0.32 \\
\hline \multicolumn{6}{|l|}{ Health history } \\
\hline Symptoms suggestive of active TB & $5(9.4 \%)$ & $5(6.3 \%)$ & $10(7.5 \%)$ & $1.6(0.4-5.7)$ & 0.52 \\
\hline BCG scar & $42(79.2 \%)$ & $59(73.8 \%)$ & $101(75.9 \%)$ & $1.36(0.6-3.1)$ & 0.54 \\
\hline Drank unpasteurized milk in the past 6 months & $10(18.9 \%)$ & $6(7.5 \%)$ & $16(12.0 \%)$ & $2.88(0.9-8.4)$ & 0.06 \\
\hline Consumed unpasteurized cheese in the last 6 months & $34(64.2 \%)$ & $48(60.0 \%)$ & $82(61.7 \%)$ & $1.19(0.6-2.4)$ & 0.72 \\
\hline Ever had contact with someone with TB disease & $18(34.0 \%)$ & $26(32.5 \%)$ & $44(33.1 \%)$ & $1.1(0.5-2.2)$ & 1.00 \\
\hline \multicolumn{6}{|l|}{ Access to health care } \\
\hline No use of healthcare in last 6 months & $12(22.6 \%)$ & $23(28.8 \%)$ & $35(26.3 \%)$ & $0.73(0.3-1.6)$ & 0.55 \\
\hline Used IMSS ${ }^{\mathrm{b}}$ in the last 6 months & $14(26.4 \%)$ & $26(32.5 \%)$ & $40(30.1 \%)$ & $0.75(0.3-1.6)$ & 0.56 \\
\hline Used IMSS ${ }^{\mathrm{b}}$ Oportunidades in the last 6 months & $16(30.2 \%)$ & $14(17.5 \%)$ & $30(22.6 \%)$ & $2.00(0.9-4.6)$ & 0.10 \\
\hline Used ISESALUD in the last 6 months & $6(11.3 \%)$ & $6(7.5 \%)$ & $12(9.0 \%)$ & $1.57(0.5-5.2)$ & 0.54 \\
\hline
\end{tabular}

a $n(\%)$ unless indicated otherwise

b Abbreviations: OR odds ratio, CI confidence intervals, IQR interquartile range, IMSS Instituto Mexicano del Seguro Social; ISESALUD: Instituto de Servicios de Salud Publica de Baja California

${ }^{c} P$-values for comparing characteristics between $\mathrm{QFT}(+)$ and QFT(-) subjects are from Wilcoxon rank sum test for continuous variables or Fisher's exact test for categorical variables

The finding of high LTBI prevalence among participants receiving benefits from IMSS Oportunidades may be explained by studies linking TB exposure to low socioeconomic status and marginalization, [25] since this program is generally offered to marginalized rural Mexican families in extreme poverty to promote social development through education and family health programs [26]. This finding should inform health officials about the potential need for increased TB education, screening, and care for patients of the IMSS Oportunidades program. Given the low number of correct answer to TB knowledge questions overall, TB education could benefit all Colonia residents as well. However, when we analyzed factors associated with answering the questions correctly, participants working as agricultural field workers had lower scores compared to non-agricultural workers $(42 \%, P=0.04)$, and there was a 
Table 3 Multivariate analysis of tuberculosis infection correlates based on QuantiFERON ${ }^{\circledR}$-TB Gold In-Tube assay testing among residents of an agricultural community in San Quintín, Baja California, Mexico: October, 2008

\begin{tabular}{llll}
\hline Characteristics & $\begin{array}{l}\text { Adjusted } \\
\text { OR }^{\mathrm{a}}\end{array}$ & {$[95 \% \mathrm{CI}]^{\mathrm{a}}$} & $P$-value \\
\hline $\begin{array}{l}\text { Any US travel since } \\
\text { living in the colonial }\end{array}$ & 2.72 & $(1.1,6.8)$ & 0.03 \\
$\begin{array}{l}\text { Drank unpasteurized milk } \\
\text { in the past 6 months }\end{array}$ & 3.60 & $(1.2,11.1)$ & 0.02 \\
$\begin{array}{l}\text { Access to IMSS Oportunidades } \\
\text { health services }\end{array}$ & 2.51 & $(1.1,5.9)$ & 0.03 \\
\hline
\end{tabular}

OR odds ratio, $C I$ confidence interval, IMSS Instituto Mexicano del Seguro Social

a All variables are adjusted for the other variables in the table by multivariate logistic regression analysis

positive correlation between the number of years of school and number of questions answered correctly $(r=0.27$, $P<0.01$ ) (data not shown). Thus, education in general for agricultural workers could improve health literacy overall.

Some limitations should be considered when interpreting the results of this study. QFT results cannot differentiate between LTBI and active disease so our interpretation of LTBI among individuals with a positive test could include individuals with active TB. However we used a TB symptom survey previously used in Mexico [7] to identify participants with possible active TB; among the 10 participants with suggestive symptoms, TB was ruled out subsequently by clinical evaluation and sputum testing at the local public health center according following the Official Mexican Guidelines for TB Control [27]. Recruitment from two sources (i.e., clinic patients and household sampling) could have produced disparate samples. However, the only difference observed between the samples was that clinic patients were more likely to speak indigenous languages and this variable was not a confounder in the final model. Another limitation that should be considered is the use of self-reported data in our survey which is subject to recall errors; however, since we performed QFT testing after the questionnaire, it is unlikely that recall problems would have occurred differentially between groups by QFT results status. A strength of this study was the use of the QFT assay, which does not crossreact with antigens in the BCG vaccine like the TST, allowing increased confidence in the results.

\section{Conclusions}

The high prevalence of LTBI among Colonia residents in San Quintín is a serious public health concern with binational ramifications given the risk of LTBI becoming active in the presence of the myriad risk factors including low socioeconomic status and frequent migration among this population. This lends further emphasis to consider addressing national strategies to target populations with LTBI for prophylactic treatment. Collaborative binational initiatives to further understand the role of migration and cross-border TB transmission combining epidemiological research, TB education and care among vulnerable migrants are critical to further advance common goals of TB elimination. Future collaborative efforts, like VIIDAI, can be useful to elucidate health conditions, educate underserved populations, and disseminate information that may be used by health care providers and policy makers.

Acknowledgments Funding and additional support were provided by the Rotary Club and the Fred H. Bixby Foundation. We wish to thank the Profesor Javier Martínez (Principal of Escuela Primaria Federal Bilingüe "Salvador Díaz Mirón") and the residents of Colonia Lomas de San Ramon. We also wish to acknowledge the support of Dr. Elvira Ibarra and Angelica Cordoba, RN from ISESALUD who provided QFT results and provided clinical followup to participants who tested positive or referred symptoms suggestive of active TB. Special thanks to Lucy Cunningham, and all the students and faculty for their dedication to the project and to the residents of Colonia Lomas de San Ramon for their support and participation in the study.

Funding Sources Funding for QuantiFERON testing was provided by the United States Agency for International Development (USAID Grant \#GSM-025). During the study period, Dr. Burgos was funded under National Institute of Allergy and Infectious Diseases T32 grant (T32-AI07384) and presently by a diversity supplement from the National Institute of Drug Abuse (DA023877-S2). VIIDAI is partially funded through the Fred J Bixby Foundation (Grant \#C03093).

Open Access This article is distributed under the terms of the Creative Commons Attribution Noncommercial License which permits any noncommercial use, distribution, and reproduction in any medium, provided the original author(s) and source are credited.

\section{References}

1. Baltussen R, Floyd K, Dye C. Achieving the millennium development goals for health-Cost effectiveness analysis of strategies for tuberculosis control in developing countries. BMJ. 2005; 331(7529):1364-8.

2. Alonso Rodriguez N, Chaves F, Inigo J, Bouza E, Garcia de Viedma D, Andres S, et al. Transmission permeability of tuberculosis involving immigrants, revealed by a multicentre analysis of clusters. Clin Microbiol Infect. 2009;15(5):435-42.

3. WHO. WHO Report 2009: Global tuberculosis control, surveillance, planning, financing. Geneva: World Health Organization (WHO); 2009 [updated 2009; cited 2010 January 15]; Available from: http://www.who.int/tb/publications/global_report/2009/pdf/ full_report.pdf.

4. WHO. Tuberculosis Fact Sheet. Geneva; 2007 [updated 2007 March 2007; cited 2010 January 15]; Available from: http://www. who.int/mediacentre/factsheets/fs104/en/. 
5. Diagnostic Standards and Classification of Tuberculosis in Adults and Children. This official statement of the American thoracic society and the centers for disease control and prevention was adopted by the ATS board of directors, July 1999. This statement was endorsed by the council of the infectious disease society of America, September 1999. Am J Respir Crit Care Med. 2000; 161(4 Pt 1):1376-95.

6. Miller TL, Hilsenrath P, Lykens K, McNabb SJN, Moonan PK, Weis SE. Using cost and health impacts to prioritize the targeted testing of tuberculosis in the United States. Ann Epidemiol. 2006;16(4):305-12.

7. Burgos JL, Kahn JG, Strathdee SA, Valencia-Mendoza A, Bautista-Arredondo S, Laniado-Laborin R, et al. Targeted screening and treatment for latent tuberculosis infection using QuantiFERON-TB Gold is cost-effective in Mexico. Int J Tuberc Lung Dis. 2009;13(8):962-8.

8. Efficacy of various durations of isoniazid preventive therapy for tuberculosis: five years of follow-up in the IUAT trial. Bulletin of the World Health Organization. 1982; 60:555-64.

9. Harada N, Nakajima Y, Higuchi K, Sekiya Y, Rothel J, Mori T. Screening for tuberculosis infection using whole-blood interferon-gamma and mantoux testing among Japanese healthcare workers. Infect Control Hosp Epidemiol. 2006;27(5):442-8.

10. Schneider E, Laserson KF, Wells CD, Moore M. Tuberculosis along the United States-Mexico border, 1993-2001. Rev Panam Salud Publica. 2004;16(1):23-34.

11. Salud Mexico: 2004. Direccion General de Evaluacion y Desempeño; 2005.

12. Gonzalez RS. Aspectos sociodemográficos de la frontera norte. In: Rangel MG, Hernandez-Avila M, editors. Condiciones de salud en la forntera norte de México. 1st ed. Mexico, D.F: El Colegio de la Frontera Norte; 2009. p. 17-38.

13. Baja California Situación Demográfica. Mexicali: Gobierno del Estado de Baja California; [January 19 2010; cited 2010 January 15]; Available from: http://www.bajacalifornia.gob.mx/portal/ nuestro_estado/historia/transformacion.jsp.

14. LoBue PA, Moser KS. Screening of immigrants and refugees for pulmonary tuberculosis in San Diego county, California*. Chest. 2004;126(6): 1777-82.

15. UABC. VIIDAI: Viaje Interinstitucional de Integracion Docente Asistencial e Investigacion. Tijuana; [cited 2010 January 31]; Available from: http://www.viidai.com/.

16. Cifras XII Censo General de Población y Vivienda [database on the Internet]; 2009. Available from: www.conapo.gob.mx/00cifras/ proy/localidad.xls.
17. SEDESOL. Programa de Desarrollo Urbano de los Centros de Poblacion: San Quintin-Vicente Guerrero. Ensenada; 2007 [updated 2007; cited 2010 May 28]; Available from: http:// www.ensenada.gob.mx/Elementos/Transparencia/docs/planes/plandesurb-sq.pdf.

18. Gonzalez-Fagoaga JE, Cruz-Piñeiro R, Rangel MG. Servicios de salud en migrantes indigenas en San Quintín, Baja California. In: Rangel MG, Hernandez-Avila M, editors. Condiciones de salud en la forntera norte de México. 1st ed. Mexico, D.F: El Colegio de la Frontera Norte; 2009. p. 285-96.

19. Rodwell TC, Moore M, Moser KS, Brodine SK, Strathdee SA. Tuberculosis from mycobacterium bovis in binational communities, United States. Emerg Infect Dis. 2008;14(6):909-16.

20. RHG Espinoza-OrtizVE, Garcia-Hernandez LA. Marketing channels and margins of raw milk produced in a family system (case study). Vet Mex. 2008;39(1):16.

21. Cellestis. QuantiFERON TB Gold (In-Tube Method). Valencia, CA: Cellestis Inc.; 2007 [updated 2007; cited 2007 4th December]; Available from: http://www.cellestis.com/IRM/Company/ ShowPage.aspx?CPID=1370.

22. Mazurek GH, Jereb J, LoBue P, Iademarco MF, Metchock B, Vernon A. Guidelines for using the QuantiFERON (R)-TB gold test for detecting Mycobacterium tuberculosis infection, United States. Morb Mortal Wkly Rep. 2005;54(RR15, Suppl. S):49-55.

23. Sun G-W, Shook TL, Kay GL. Inappropriate use of bivariable analysis to screen risk factors for use in multivariable analysis. J Clin Epidemiol. 1996;49(8):907-16.

24. Rodwell TC, Moore M, Moser K, Brodine S, Strathdee S. Mycobacterium bovis tuberculosis in binational communities. Emerg Infect Dis. 2008;14(6):909-16.

25. Sanchez-Perez H, Flores-Hernandez J, Jansa J, Cayla J, MartinMateo M. Pulmonary tuberculosis and associated factors in areas of high levels of poverty in Chiapas, Mexico. Int J Epidemiol. 2001;30(2):386-93.

26. Gomez-Vinales C, Herrera-Segura J, Solano-Mejia B. Health actions to become integrated into IMSS-oportunidades. Rev Med Inst Mex Seguro Soc. 2008;46(2):223-32.

27. SSA. Modificación a la Norma Oficial Mexicana NOM-006-SSA21993, Para la prevención y control de la tuberculosis en la atención primaria a la salud. Mexico City, Mexico: Secretaría de Salud; 2005 [updated 2005; cited 2008 January 21]; Available from: http:// www.salud.gob.mx/unidades/cdi/nom/m006ssa23.html. 